\section{Italy launches clinical trial for HIV vaccine}

Controversy is surrounding a phase II clinical trial of an HIV vaccine that began in Italy this month.

Led by Barbara Ensoli of the ISS in Rome, Italy's major health research laboratory, the trial is testing a vaccine based on a protein called Tat, which is involved in the replication of HIV.

But critics, including HIV co-discoverer Robert Gallo of the University of Maryland School of Medicine in Baltimore, argue that the scientific basis for Ensoli's vaccine is weak. They note that Tat has proved ineffective in animal models in other labs.

Critics in Italy are also complaining that Ensoli's phase I trial was insubstantial, and that the government has allocated a disproportionate amount of money $\_€ 21$ million (US\$33 million) over three years - to the work.

Ensoli says that she expects the phase II trial to be looked on favourably by an ISS external committee of experts that will meet this winter.

See also pages 551 and 565

\section{Nations pool resources to study lunar seismic activity}

Representatives of nine national space agencies signed an agreement on 24 July to create an International Lunar Network, which aims to plant a system of six or more seismic stations on the Moon.

NASA scientists joined with space scientists from the United Kingdom, France, Italy, Germany, Japan, South Korea, India and Canada, and agreed to work towards setting up a core set of instruments that could measure 'moonquakes', and the thickness and composition of the Moon's crust, mantle and core.

The programme would begin with a US\$200-million 'anchor nodes' mission in 2014 , involving sending a pair of US landers

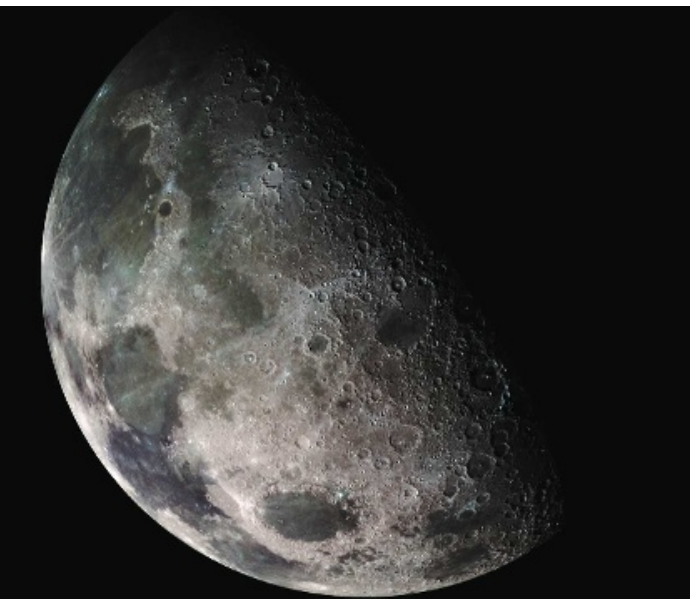

\title{
Voyage to the bottom of the world's deepest lake
}

Russian scientists are preparing to dive to the very bottom of Siberia's Lake Baikal - the deepest lake in the world, at 1,637 metres.

The expedition will use the manned submersibles Mir-1 and Mir-2 (pictured) and is led by Anatoly Sagalevich, the head of the deep manned submersibles lab at the P.P. Shirshov Institute of Oceanology in Moscow. During around 30 dives, the scientists will take water and sediment samples from Baikal and hunt for

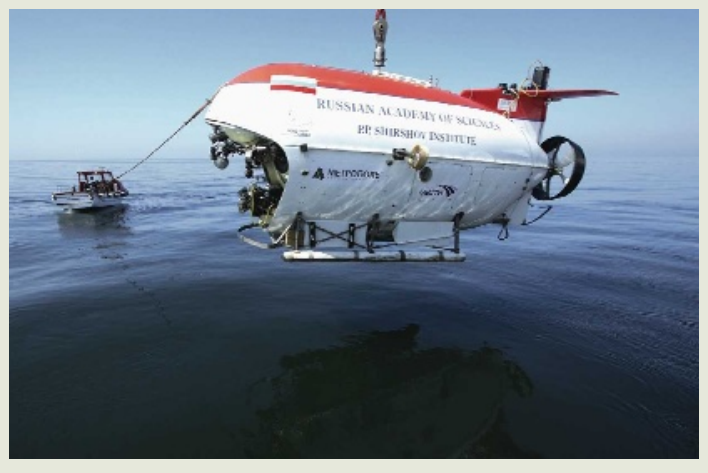

hydrothermal vents that spew superheated water into the lake.

Robert Nigmatulin, head of the Shirshov Institute, says that they aim to collect gas hydrate deposits at the bottom of the lake. Gas hydrates have been found in boreholes drilled more than 100 metres below the lake bed and also show up in seismic surveys.

The team plans to explore the lake for about a month and will return to the lake next year. For a longer version of this story, see http://tinyurl.com/6jkps8

to the poles, followed perhaps by a second mission in 2016. The European Space Agency, Russia, Ukraine and Australia are also being included in the discussions.

\section{GlaxoSmithKline cements interest in stem cells}

Drug company GlaxoSmithKline is setting up a US\$25-million, five-year collaboration with the Harvard Stem Cell Institute in Cambridge, Massachusetts. The money will support research as well as a staff exchange programme between the two partners.

Announced on 24 July, the programme is another sign of the pharmaceutical industry's growing interest in stem-cell research, once considered the domain of academics and small biotechnology companies.

The Harvard collaboration is also the latest in a spate of academic collaborations launched by the UK-based drug firm. On 21 July, the company unveiled its 'academic incubator' collaboration with the University of Cambridge, UK, which will give researchers in neuroscience and metabolic disorders a more direct role in the early clinical development of treatments for addiction and obesity.

\section{Statistics show hint of bias in NIH grant reviews}

The system used by the US National Institutes of Health (NIH) to evaluate grant proposals does not adequately compensate for reviewer bias, affecting one in four proposals, a study finds.

Valen Johnson, a biostatistician at the University of Texas M.D. Anderson Cancer Center in Houston, evaluated reviews for nearly 19,000 grant proposals performed by around 14,000 reviewers in 2005

(V. E. Johnson Proc. Natl Acad. Sci. USA doi:10.1073/pnas.0804538105; 2008).

Each application is typically read by $2-5$ reviewers, then discussed when a larger study section of about 30 reviewers meets. In the end, scores from all the study section's members - readers and nonreaders alike - are averaged together.

The system fails to account for individual bias and places undue weight on panel members who have not read the proposals, Johnson argues. He found that the top grants were largely unaffected by reader bias, but that it did affect grants closer to the funding cut-off line. Overall, accounting for reader bias changed about $25 \%$ of the funding decisions, meaning that one in four funded proposals would have been replaced by one that had not been funded. For a longer version of this story, see http://tinyurl.com/5tlhvj

\section{Bail for entomologists held for illegal insect collection}

Two Czech entomologists jailed in India on charges of illegally collecting insects were released on bail on 25 July. They are to remain in Darjeeling until their case is heard there on 12 August.

The pair were arrested in late June, for allegedly collecting beetles, butterflies and moths in a national park without proper permits (see Nature 454, 14; 2008). Petr Švácha, of the Institute of Entomology at the Biology Centre of the Academy of Sciences of the Czech Republic in Cěské Budějovice, and his colleague Emil Kučera say that to their knowledge they did not even enter the park. If convicted, they face two to seven years in prison. 